\title{
Implants with a Laser-microgrooved Collar Placed in Grafted Posterior Maxillary Extraction Sockets and in Crestally Grafted Sinuses: a 5-Year Multicentre Retrospective Study
}

\author{
Renzo Guarnieri ${ }^{1,3}$, Luca Savio $^{2}$, Alessandro Bermonds ${ }^{2}$, Luca Testarelli1 ${ }^{1,4}$ \\ ${ }^{1}$ Department of Dental and Maxillofacial Sciences, School of Dentistry, University "La Sapienza", Rome, Italy. \\ ${ }^{2}$ Private practice, Torino, Italy. \\ ${ }^{3}$ Private practice, Treviso, Italy. \\ ${ }^{4}$ Private practice, Roma, Italy.
}

\author{
Corresponding Author: \\ Renzo Guarnieri \\ Via L. Cattarin 3D, 31100 Treviso \\ Italy \\ Phone: +393425224458 \\ E-mail: renzoguarnieri@gmail.com
}

\begin{abstract}
Objectives: The aim of this retrospective multicentre cohort study was to compare clinical outcomes, soft tissues conditions and differences in marginal bone loss between implants with a laser-microgrooved collar placed in posterior maxillary extraction sockets grafted by 4 to 5 months, and in posterior maxillary pristine bone (spontaneously healed posterior maxillary extraction sockets) by means of osteotome-mediated sinus floor elevation, over a period of 5 years after functional loading. Material and Methods: Patients of Group 1 underwent extractions with sockets preservation using porcine-derived bone, covered with collagen membrane. Group 2 underwent extractions without socket preservation. Patients of Group 1 received implants in grafted sites, and Group 2 received implants in spontaneously healed bone using a maxillary sinus lift with crestal approach.

Results: Over the observation period, the overall clinical success rate in Group 1 and Group 2 was 98\% and 100\%, respectively, with no differences between the procedures and implants used. Cumulative radiographic marginal bone loss ranged from 0.03 to $0.39 \mathrm{~mm}$ after 60 months of functional loading. There were no statistically significant differences in marginal bone loss between short and standard-length implants placed in grafted extraction sockets and in pristine bone.

Conclusions: Short and standard implants with a laser-microgrooved collar, placed in posterior maxillary extraction sockets grafted by 4 to 5 months, and in posterior maxillary pristine bone (spontaneously healed posterior maxillary extraction sockets) by means of osteotome-mediated sinus floor elevation, exhibited no statistical difference in success rate, clinical parameters and marginal bone loss.
\end{abstract}

Keywords: alveolar ridge augmentation; dental implants; sinus floor augmentation; tooth extraction.

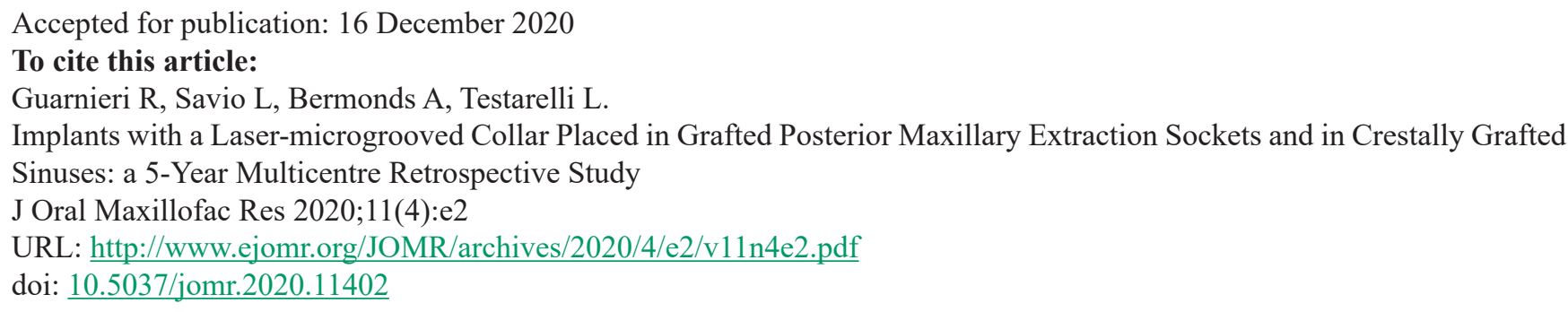




\section{INTRODUCTION}

Following tooth extraction, loss of alveolar ridge volume is an irreversible process that involves both horizontal and vertical components [1-5]. Several local and systemic factors, among which, the number of neighbouring teeth to be extracted, bony buccal plate and soft tissue thickness (periodontal biotype), smoking status, uncontrolled diabetes, bone metabolic disorders, and patient compliance, influence the degree of bone resorption and remodelling. However, with the same local and systemic conditions, the widest sockets (molars) show a significantly greater amount of resorption and require more time than the narrowest ones (incisors and pre-molars) for the formation of the bone tissue bridge over the defect $[\underline{6}, 7]$. This resorption process often results in a narrower and shorter crest, moved to a more palatal/lingual position. In turn, in longstanding posterior edentulous maxilla the absence of teeth promotes sinus pneumatisation which further reduces the vertical bone height [ $\underline{8}]$. Post extraction pneumatisation of the maxillary sinus and dimensional reduction in the residual bone crest make often complex the implants supported prosthetic rehabilitation of posterior maxillary regions [1] To treat posterior maxillary alveolar bone vertical deficiencies and to allow a proper implant placement, maxillary sinus floor elevation with lateral approach, represents a predictable surgical procedure [9]. However, this surgical technique has the potential to develop complications, to increase postoperative morbidity and costs [10]. A crestal approach in maxillary sinus floor elevation, as a less invasive surgical technique compared the lateral approach, has been first proposed by Summers [11]. The procedure involves the elevation of the Schneiderian membrane utilizing tapered osteotomies with increasing diameters that compress the bone tissue of the implant site both laterally and apically. To minimize the risk of membrane perforation later some clinicians proposed use an inflatable device or fill the void with grafting material prior fracturing the sinus wall [12]. The common aspect between Summers' technique and the authors' who modified it, is the recommendation to perform the maxillary sinus floor lift and simultaneous implant placement in alveolar crests with residual dimensions $\geq 5 \mathrm{~mm}$, which represents a minimum reference height in order to obtain a high predictability rate [13]. In the attempt to simplify the implant treatment plan and counteract bone volume loss associated with outcomes of tooth extractions, immediate implant placement with or without simultaneous regenerative procedures and alveolar ridge preservation (ARP) techniques have been proposed as simultaneous procedures to teeth removal [14-21]. Although several literature data indicated that success rates of implants immediately placed in extraction sites are similar to those of implants placed in healed extraction sites, due the presence of larger extraction sockets, poor quality of bone, and less apical bone availability for the proximity of maxillary sinus, clinicians commonly avoided immediate implant placement in maxillary molar extraction sockets [22]. Moreover, it has also been well documented that, as regards the volumetric changes of the postextraction sockets, immediate implant placement with or without simultaneous regenerative procedures, does not totally counteract alveolar ridge modelling [23]. ARP techniques performed in the posterior maxilla have been demonstrated to reduce volumetric contraction compared the one observed in extraction sites of the same area spontaneously healed [24,25]. Moreover, the effectiveness of ARP procedures has been documented also in preventing maxillary sinus expansion, showing sites treated significant differences in terms of post-extractive pneumatisation compared to sites with spontaneous healing [26]. Different grafting materials, including autografts, allografts, alloplasts, and xenografts, with and without absorbable or non-absorbable membranes have been proposed for ARP. To date, a body of knowledge is available in the literature containing a wide range of clinical, radiographic and histological results. However, there is still no consensus for case selection, clinical technique, or material choice, and conclusions of several systematic reviews [14-23] on the topic do not support the use of a technique, or material, as superior. A number of publications indicated that, among xenografts, porcine-derived bone owns excellent osteoconductive properties without adverse reactions $[19,27-28]$. Nevertheless, as for the other xenografts, when used in ARP techniques [20,21], porcine-derived bone is not completely reabsorbed [29-32] and residual graft particles remain incorporated in newly formed bone tissue and maintained as inactive fillers. While most of osseous support of implants placed in pristine maxillary bone simultaneously to maxillary sinus lift with crestal approach is exclusively constituted by native bone (at least $5 \mathrm{~mm}$ ), in cases that involve ARP procedures remaining graft particles may also be part of the peri-implant tissue. In the latter, marginal support of implant is provided by a variable amount of native bone, depending on the original remaining alveolar bone height. It is generally accepted that, in order to ensure long-term survival and success of functionally loaded implants, the peri-implant 
osseous substrate should have the same intrinsic structural and physiological characteristics of native bone. Since marginal bone loss (MBL) is usually around the coronal end of the implant, differences in biomechanical and biological properties of the tissue that directly interfaces with the implant collar could result in different responses after functional loading. In this regard, a finite element analysis indicated that load distribution around implants placed in grafted areas may be strongly conditioned by the characteristics of the residual graft particles [33-35]. When the grafted volume exhibits less stiffness than the native bone, functional loading produces an increased concomitant stress at the level of the crestal bone. However, finite element studies require a precautionary interpretation and limited clinical information are present in literature.

This retrospective multicentre cohort study was aimed to evaluate retrospectively clinical outcomes and differences in marginal bone loss between implants with a laser- microgrooved collar placed using two different surgical protocols (implants placed in posterior maxillary pristine bone using a maxillary sinus lift with crestal approach and placed in maxillary posterior extraction sockets regenerated by 4 to 5 months with porcine-derived bone and porcine collagen membrane), in two different patient groups, over a period of 5 years after functional loading. The test hypothesis was that there were no differences in soft tissues conditions and in marginal bone loss between implants with a laser-microgrooved collar placed using the two procedures, against the alternative hypothesis of a difference.

In addition, the influence of age, gender, smoking habits, history of periodontal disease, type of implant (short and standard-length), on marginal bone loss was analysed in function of the type of osseous support (previously grafted or pristine).

\section{MATERIAL AND METHODS Study population}

All subjects were selected from 4 private practice pools following these inclusion criteria: 18 - 75 years of age, physical status according to the American Society of Anesthesiologists (ASA) I or II, absence of systemic diseases or conditions known to alter bone metabolism, and presence of one hopeless tooth with a non-restorable lesion, endodontic treatment failure, or root fracture, or periodontal and endoperiodontal non-treatable lesion. All records contained standardized digital intraoral radiographies obtained at the time of implant placement (baseline [BSL]), final restoration delivery (FRD), and 1, 2, 3, 4, 5 years later after functional loading. Subjects were excluded if they had a history of intake of medications known to modify bone metabolism (e.g., bisphosphonates). Likewise, subjects who developed acute or chronic sinus pathology (i.e., sarcoidosis, osteomas, carcinomas, cancer of any kind, or had postoperative complications related to the procedures described in this study were excluded.

Italian law does not require any ethical committee authorization for clinical trials performed in private dental offices. Such authorization is required for public dental health centres (DM 18/3/1998 published in the Official Gazette, GU n. 122 of 28-05-1998). Therefore, the study was granted an exemption by the University "La Sapienza", Roma, Italy review board. All patients signed informed consent documentation in which all procedures were detailed. The study was conducted in compliance with the Declaration of Helsinki.

Consecutive patients that fulfilled the inclusion criteria were elected for this study which was conducted between January 2013 and December 2020 in 4 private clinical centres at Treviso, Torino (two centres) and Roma in Italy. The study population was divided into two cohorts of subjects. The first cohort (Group 1) underwent extractions with sockets preservation using porcine-derived bone covered with collagen membrane and, following 6 months, dental implants with standard approach. Patients of Group 2 underwent extractions without socket preservation and, following 6 months, received dental implants in spontaneously healed bone using a maxillary sinus lift with crestal approach (Figure 1).

\section{Implants}

Two implants were used:

- Short length implant (SH): Tapered Short Implant Laser-Lok $^{\circledR} \quad$ (BioHorizons Inc.; Birmingham, Alabama, USA) with tapered body design and resorbable blast textured (RBT) body surface, a $1.8 \mathrm{~mm}$ laser micro-grooved coronal design, with $4.6 / 5.8 \mathrm{~mm}$ in diameter and 6 and $7.5 \mathrm{~mm}$ in length.

- Standard length implant (ST): Tapered Internal Implant Laser-Lok ${ }^{\circledR}$ (BioHorizons Inc.) with tapered body design and RBT body surface, a 1.8 $\mathrm{mm}$ laser micro-grooved coronal design, with a $3.8 / 4.6 \mathrm{~mm}$ in diameter and $9 / 12 \mathrm{~mm}$ in length.

According to the manufacturer's recommendation, in each group of patients (1 and 2), all implants were placed with $0.9 \mathrm{~mm}$ of the laser-mocrogrooved surface above the bony crest, and with $0.9 \mathrm{~mm}$ of the laser-mocrogrooved surface under the bony crest. 


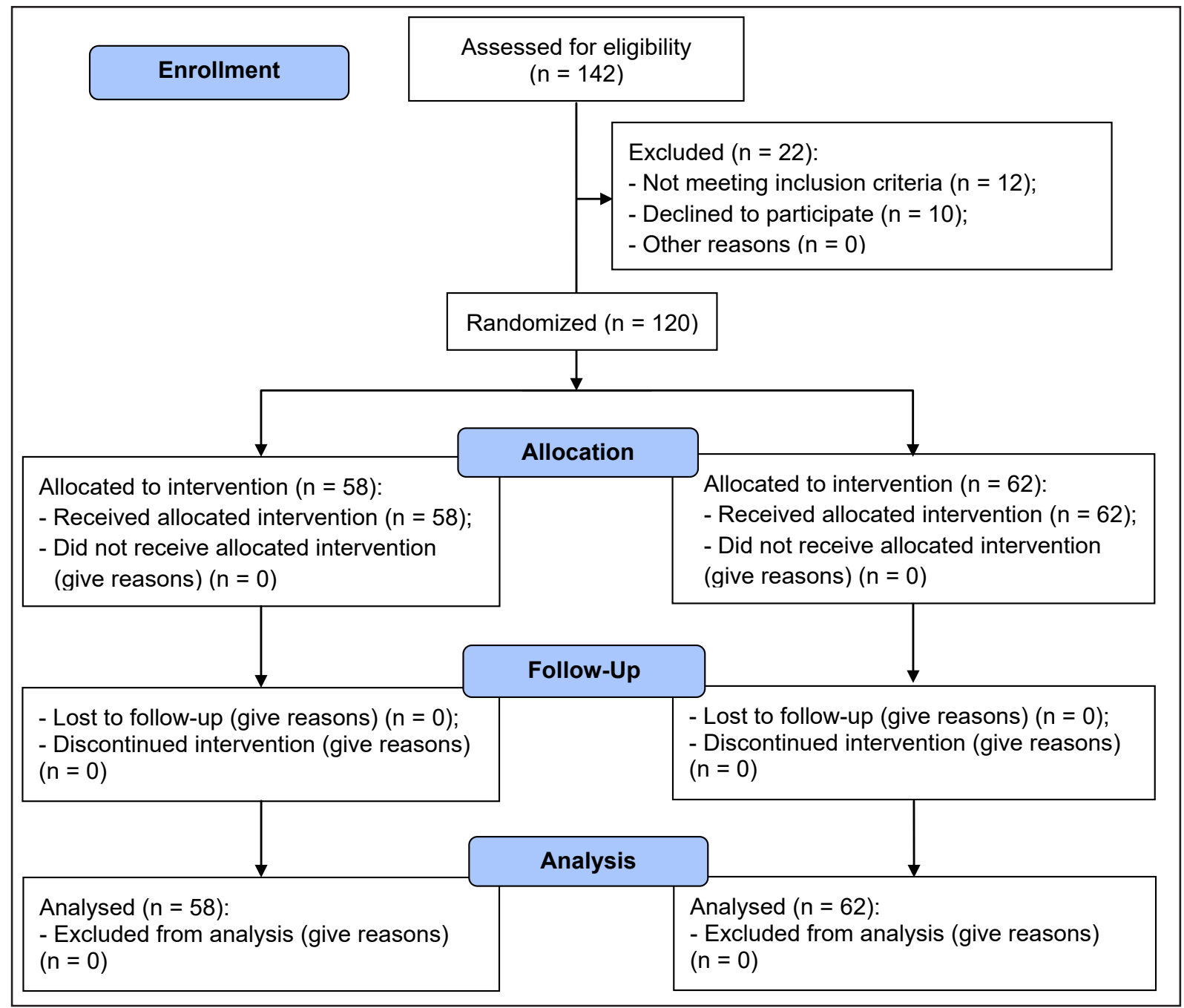

Figure 1. The CONSORT flow diagram.

In all patients, full-mouth intraoral radiographies, cone-beam computer tomographic (CBCT) scans, diagnostic wax patterns, and surgical templates were used for the presurgical evaluations. Cumulative success rates, peri-implant MBL, probing depth (PD), plaque index (PI), bleeding on probing (BOP), and gingival recession were recorded at definitive restoration delivery, and at each year during the follow-up period.

\section{Surgical procedures}

All patients were prescribed prophylactic antibiotic therapy with $2 \mathrm{~g}$ of amoxicillin $\left(\mathrm{Zimox}^{\circledR}\right.$ - Pfizer Italia Srl; Latina, Italy), or clindamycin $600 \mathrm{mg}$ $\left(\right.$ Dalacin $^{\circledR} \mathrm{C}$ - Pfizer Italia Srl; Latina, Italy) if allergic to penicillins) $1 \mathrm{~h}$ before the extraction procedure and continued postoperatively with $1 \mathrm{~g}$ of amoxicillin $\left(\right.$ Zimox $\left.^{\circledR}\right)$ or $300 \mathrm{mg}$ clindamycin $\left(\right.$ Dalacin $^{\circledR}$ C) twice a day for 5 days. In addition, rinsing for $1 \mathrm{~min}$ with chlorhexidine mouthwash $0.2 \%$ (Curasept ADS $^{\circledR}-$ Curadent Healthcare
S.p.A.; Saronno, Varese, Italy) prior to the surgery, and twice a day for the following 3 weeks, was recommended.

In the Group 1, following local anaesthesia with $2 \%$ lidocaine with adrenaline $1: 50,000$, (Xylocaina $^{\circledR}$ - AstraZeneca S.p.A.; Italy), the identified tooth was extracted in a minimally traumatic manner with periotomes and without raising a full thickness flap. If necessary, the tooth was sectioned. Following preparation of interdental papilla with a pouch procedure, the extraction sockets were grafted with porcine-derived bone (MinerOss $\mathrm{XP}^{\circledR}$ - BioHorizons Inc.) up to the buccal and palatal alveolar bone walls and, subsequently, a collagen membrane (Mem-Lok Pliable $^{\circledR}$ - BioHorizons Inc.) was gently pushed under the interdental papilla with the use of periotomes. The collagen membrane was used to cover the fresh extraction socket entrance. A 4.0 or 5.0 monofilament suture (Omnia ${ }^{\circledR}$ PTFE - Omnia SpA; Fidenza, Parma, Italy) was used to stabilize the membrane and prevent loss of graft particles. The collagen membrane was left exposed. 
In the Group 2, following local anaesthesia with $2 \%$ lidocaine with adrenaline $1: 50,000\left(\right.$ Xylocaina $\left.^{\circledR}\right)$, the identified tooth was extracted in a minimally traumatic manner with periotomes and without raising a full thickness flap. If necessary, the tooth was sectioned. Soft tissues were approximated and sutured with a 4.0 or 5.0 monofilament suture (Omnia ${ }^{\circledR}$ PTFE).

In both groups, after over 4 to 5 months of healing, the surgical re-entry procedure was performed for implant placement. Before surgery, in each site, the keratinized tissue thickness (KTT) was measured after performing anaesthesia, by means of n. $30 \mathrm{~K}$-file inserted until touching the bone crest. The KTT was dichotomized into two groups $(\leq 2 \mathrm{~mm}$ and $>2 \mathrm{~mm})$. In the Group 1, SH and ST implants were placed according to conventional implant placement protocol at a minimum distance of $\geq 1.5 \mathrm{~mm}$ from the adjacent natural teeth. After local anaesthesia, surgical access was carried out with a full-thickness flap at the level of keratinized mucosa with a minimally extended release incision to expose the crest and the vestibular limit of the bone. Utmost care was taken to preserve the periodontal integrity of adjacent teeth. Following implant placement, the flap was sutured without tension using 4.0 or 5.0 monofilament sutures which were left in place for 10 days. Patients were instructed to have a liquid or semiliquid diet for the first three days and gradually return to a normal diet. An analgesic (Ibuprofen ${ }^{\circledR} 600$ mg - Kern Pharma SL; Terrassa, Spain) was prescribed immediately after surgery and after 8 hours.

In the Group 2, implant site was carried-out using only Summers' osteotomes with increasingly larger diameters numbers 1,2 and 3 , which were rotated and pressed manually to reach the working depth. By means of an alveolar curette (Lucas HFCL 84E5), the membrane was detached for about $1 \mathrm{~mm}$, in a circumferential direction in relation to the access hole. Subsequently, collagen - accurately dimensioned, i.e. cut in small cubes with sides measuring $3 \mathrm{~mm}$ - was positioned and by means of the osteotomes, which were never pushed beyond the sinus floor, it was compacted toward the membrane in 5 - 6 times subsequently. Small amounts of grafting material, composed of porcine demineralized bone (MinerOss $\mathrm{XP}^{\circledR}$ ) were added 4 - 5 times subsequently and carefully compacted with osteotome no. 3 , to reach a maximum depth of $5 \mathrm{~mm}$. At the end of this procedure, the osteotome was pushed delicately to a depth of $1 \mathrm{~mm}$ less than the original implant length) and the negativity of Valsalva's sign was verified. ST implants were placed, with the rough/microgrooved border flush with the bone crest, with the lasermicrogrooved surface at the supra crestal level, and at a minimum distance of $\geq 1.5 \mathrm{~mm}$ from the adjacent natural teeth.

Postoperative instructions were given, and all patients were prescribed Ibuprofen ${ }^{\circledR} 600 \mathrm{mg}$ tablets. In all patients, the second-stage surgery for placement of healing abutments was performed after 4/6 months. The implant supported prosthetic restorations were delivered in each implant site after 5 and 7 months.

\section{Follow-up}

After FRD, patients were enrolled in a maintenance program with half-yearly recalls. At each control visit, a professional oral hygiene and a clinical/radiographic examination was performed. Number of sites with plaque, number of sites with BOP, PD, mucosal recession (REC), and mesial/distal radiographic periimplant marginal bone levels were considered at the each recall visit. Moreover, prosthesis mobility, pain, infection, and any complications, if present, were recorded. Absence of mobility, pain, infection, and radiolucent area around the implant were considered parameters of success. Implant loss, implant/screw fracture that conditions the prosthesis stability, significant bone loss $(>3 \mathrm{~mm})$ and lack of osseointegration were considered parameters of failure.

\section{Radiographic examinations}

Digital radiographs (Figure 2 and 3) were taken with an individualized acrylic resin device fixed to the residual dentition and a radiograph holder. Radiographic measurements were calculated using a software program VixWin ${ }^{\mathrm{TM}}$ Platinum Imaging Software (Gendex Dental Systems; Des Plaines, Illinois, USA). Radiographically, MBL was assessed at the mesial and the distal sides of each implant by subtracting the measure of MBL at the BSL from the measure of MBL at RD, and 1, 2, 3, 4, 5-year followup. A dedicate software (VixWin ${ }^{\mathrm{TM}}$ Platinum Imaging Software) was used to calculate the radiographic measurements. The following radiographic measurements were performed:

- Radiographic implant length (IL): distance (in $\mathrm{mm}$ ) between the implant coronal margin and the implant apex as assessed at the mid portion of the implant.

- Residual bone height at the mesial and distal aspects of the implant: distance (in $\mathrm{mm}$ ) between the line linking the coronal implant margin, and the first contact of the crestal bone on both mesial and distal sides of the implant.

To account for radiographic distortion, radiographic 


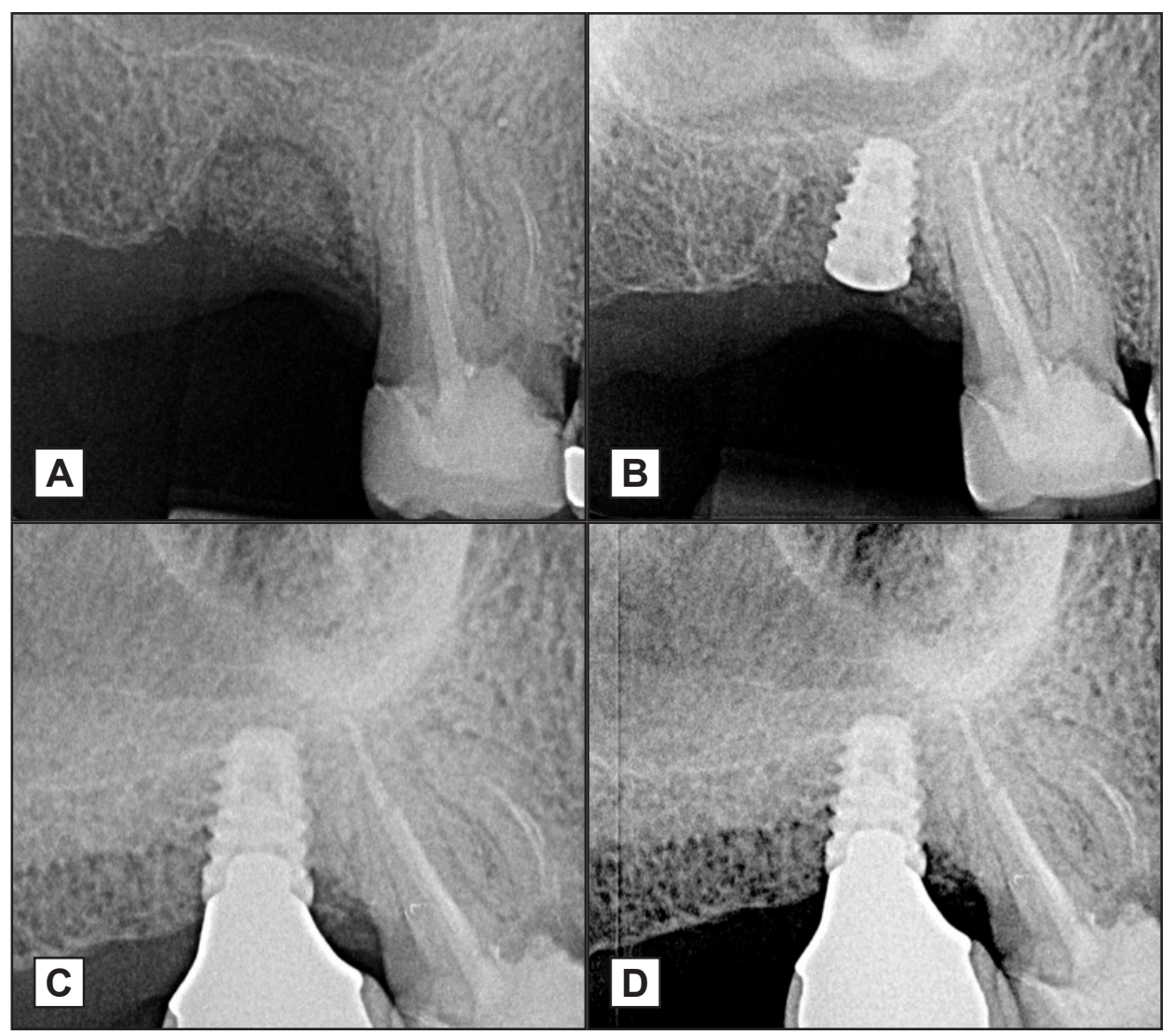

Figure 2. Example of treatment in Group 1.

$\mathrm{A}=$ the extraction socket was grafted with porcine-derived bone; $\mathrm{B}=$ after 6 month a short implant was placed; $\mathrm{C}=$ crown delivery; $\mathrm{D}=5$ years follow-up.

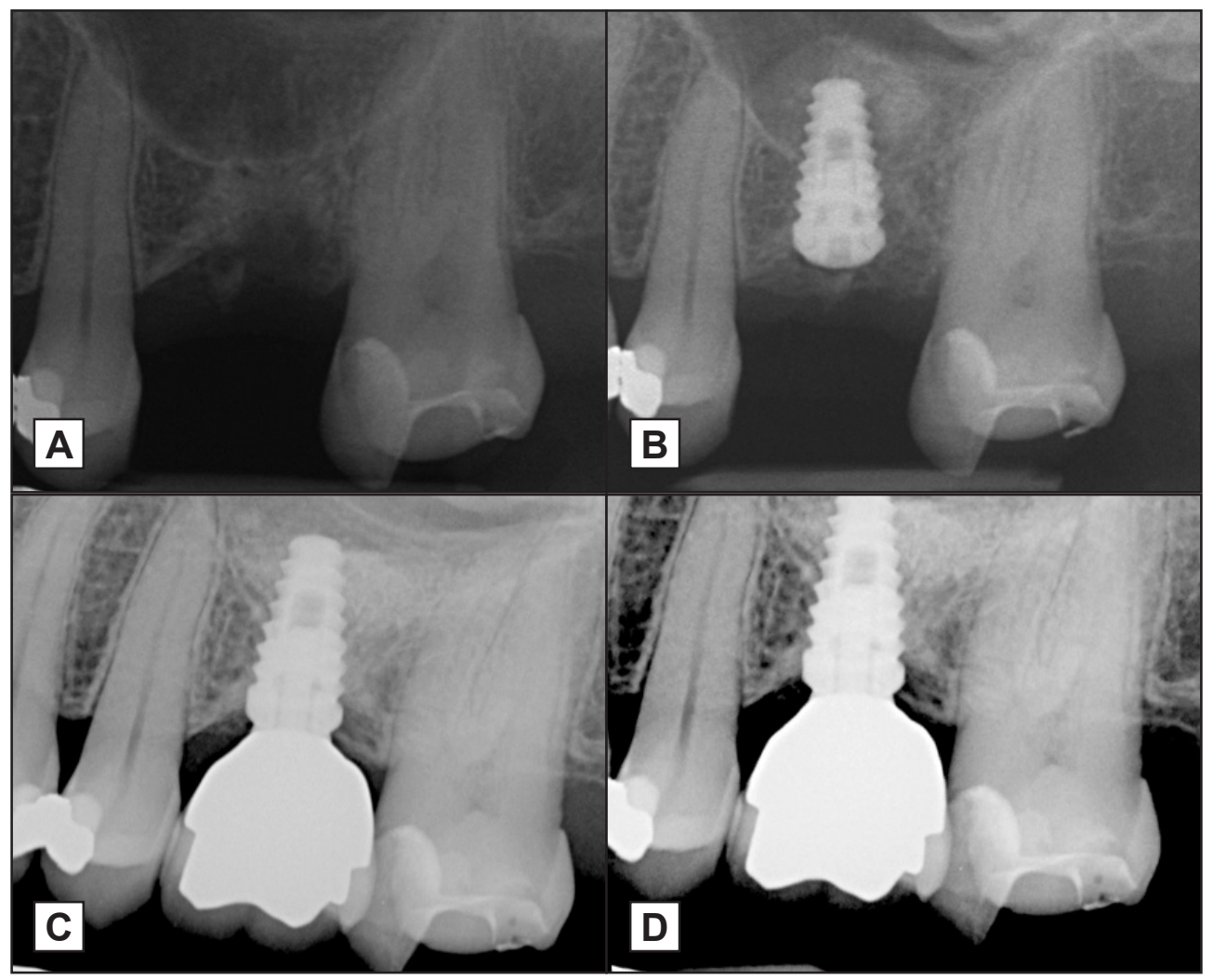

Figure 3. Example of treatment in Group 2.

$\mathrm{A}=$ the extraction socket was no grafted; $\mathrm{B}=$ after 6 month a standard implant was placed by means of a crestal sinus floor elevation; $\mathrm{C}=$ crown delivery; $\mathrm{D}=5$ years follow-up. 
measurements on each radiograph were adjusted for a coefficient derived from the ratio: true length of the implant/IL.

\section{Additional data recorded}

Age, sex, smoking, and drinking habits at the time of enrolment in the study, history of periodontal disease, and type of implant (SH or ST), were recorded for each subject. Smoking habits were classified using the following criteria:

- Non-smoker: 0 cigarette/day;

- Mild smoker: 0 - 10 cigarette/day;

- Heavy smoker: $>10$ cigarette/day.

Alcohol intake was considered over $10 \mathrm{gr} /$ day. History of periodontal disease was determined by consulting dental history records. If not available, information was gathered by asking the subject about past dental care and performing a comprehensive periodontal examination. At least $3 \mathrm{~mm}$ of attachment loss and $30 \%$ of radiographic bone loss in $30 \%$ of sites was considered to classify periodontally compromised patients.

\section{Examiner calibration}

All the clinical outcome variables were carried out by a single trained examiner (RG) who had previously undergone a calibration session on a sample of 10 patients treated with the same implant system and not included in the study (kappa test $=0.9418$, $\mathrm{SE}$ of $\mathrm{kappa}=0.09,95 \%$ confidence interval $=$ 0.8417 to 1$)$.

\section{Statistical analysis}

For clinical parameters (PD and REC) and radiographic MBL, data was calculated for each implant and reported as mean and standard deviation (M [SD]). Number of sites with plaque, and number of sites with bleeding at BSL, FRD, 1, 2, 3, 4, 5 years were also reported. The normality of distribution of variables was controlled by the KolmogorovSmirnov test. Bonferroni test was used for multiple comparisons between two groups (1 and 2). Parametric test assumptions were not available for PI and BOP, thus, these variables were analysed with the Wilcoxon signed rank test. The results of Wilcoxon signed rank test were expressed as the number of observations (n) and M (SD). An alpha error of 0.05 was set to accept a statistically significant difference. MBL was expressed as average values (in $\mathrm{mm}$ ) in function of type of bone, interproximal site, time elapsed since functional loading, and type of implant.
One-way analysis of variance (ANOVA) was performed to identify the categorical variables (gender, history of periodontitis, and smoking) significantly associated with MBL. The relationship between MBL and age was determined by calculating the Pearson correlation coefficient. The effect of two variables of interest, type of bone (grafted versus pristine), and type of implant (SH versus ST), relative to MBL was analysed using analysis of covariance (ANCOVA). In this analysis, there were two repeated-measures factors: elapsed time since surgery $(1,2,3,4,5$ years) and location of the MBL (mesial or distal). The Greenhouse-Geisser correction was used to correct for violation of the sphericity assumption for all decisions in which repeated-measures factors with more than 2 levels were involved. All the analyses were carried out using statistical software SPSS Statistics 15.0 (IBM Corp.; Armonk, New York, USA).

\section{RESULTS}

One hundred and twenty subjects (74 [61.6\%] females) participated in this retrospective multicentre cohort study. Age ranged from 30 to 72 years (mean $=54.18$ years). A total of 58 subjects were enrolled in Group 1 and 62 subjects formed Group 2. Therefore, 120 implants were evaluated. Thirtythree implants in Group 1 were SH and 25 were ST. Thirty-five SH implants and 27 ST were allocated in Group 2 (Table 1). Mean values of PI, BOP, PPD, REC, recorded in both groups at the end of the follow-up period are reported in Table 2 .

Table 1. Demographic data

\begin{tabular}{l|c|c|c}
\hline \multirow{2}{*}{ Total patients } & Total & Group 1 & Group 2 \\
\cline { 2 - 4 } & N (\%) & N (\%) & N (\%) \\
\hline Total implants & $120(100)$ & $58(48.3)$ & $62(51.7)$ \\
\hline Short length implant & $120(100)$ & $58(48.3)$ & $62(51.7)$ \\
\hline Standard length implant & $52(56.6)$ & $33(56.8)$ & $35(56.4)$ \\
\hline Male & $46(38.4)$ & $22(47.8)$ & $24(53.2)$ \\
\hline Female & $74(61.6)$ & $34(45.9)$ & $40(54.1)$ \\
\hline No smokers & $72(60)$ & $32(44.4)$ & $40(45.6)$ \\
\hline Mild smoker & $37(30.8)$ & $17(45.9)$ & $20(54.1)$ \\
\hline Heavy smoker & $11(9.2)$ & $6(54.5)$ & $5(45.5)$ \\
\hline Periodontitis & $42(35)$ & $20(47.6)$ & $22(52.4)$ \\
\hline No periodontitis & $78(65)$ & $43(55.1)$ & $35(44.9)$ \\
\hline Alcohol intake & $53(44.1)$ & $28(52.8)$ & $25(47.2)$ \\
\hline No alcohol intake & $67(47.7)$ & $32(53.3)$ & $35(52.3)$ \\
\hline
\end{tabular}

$\mathrm{N}=$ number. 
Table 2. Results of the clinical measurements for implants in both groups collected at the end of the follow-up period (5 years)

\begin{tabular}{|c|c|c|}
\hline Group & $\begin{array}{c}\text { Mean (SD), } \\
\text { mm }\end{array}$ & P-significance \\
\hline \multicolumn{3}{|l|}{ Plaque index } \\
\hline Non-regenerated & $21(12)$ & \multirow{2}{*}{$0.5748^{\mathrm{a}}$} \\
\hline Regenerated & $19(14)$ & \\
\hline \multicolumn{3}{|c|}{ Bleeding on probing } \\
\hline Non-regenerated & $8(2.3)$ & \multirow{2}{*}{$0.7943^{\mathrm{a}}$} \\
\hline Regenerated & $9(2.1)$ & \\
\hline \multicolumn{3}{|c|}{ Probing pocket depth } \\
\hline Non-regenerated & $1.2(0.6)$ & \multirow{2}{*}{$0.6783^{\mathrm{b}}$} \\
\hline Regenerated & $1.3(0.3)$ & \\
\hline \multicolumn{3}{|c|}{ Mucosal recession } \\
\hline Non-regenerated & $0.6(0.3)$ & \multirow{2}{*}{$0.8137^{\mathrm{b}}$} \\
\hline Regenerated & $0.5(0.7)$ & \\
\hline \multicolumn{3}{|c|}{ Keratinized mucosa } \\
\hline Non-regenerated & $2.6(1.3)$ & \multirow{2}{*}{$0.7892^{\mathrm{b}}$} \\
\hline Regenerated & $2.8(1.2)$ & \\
\hline
\end{tabular}

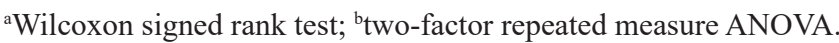
$\mathrm{SD}=$ standard deviation

The mean PI values at the implant sites reached 21 (12)\% for the Group 1, and 19 (14)\% for the Group 2. In both groups, the mean BOP value reached 8 (2.3)\%, and $9(2.1) \%$, respectively, and the mean PPD value was $1.2(0.6) \mathrm{mm}$ and $1.3(0.3) \mathrm{mm}$, respectively. The mean REC value recorded for the Group 1 was $0.6(0.3) \mathrm{mm}$, and $0.5(0.7) \mathrm{mm}$ for the Group 2.
No significant difference between the two groups was noted for PI, BOP, PPD, and REC. In $89 \%$ of the sites in the Group 1 and $83 \%$ in the group 2, keratinized mucosa (KM) was present at the buccal aspect, with similar mean values in height (Group $1=2.6$ [1.3] $\mathrm{mm}$; Group $2=2.8$ [1.1] mm). In both groups, no statistically significant difference was noted in MBL between sites with KTT $>2 \mathrm{~mm}$ and $\leq 2 \mathrm{~mm}$.

Cumulative radiographic MBL ranged from 0.03 $\mathrm{mm}$ to $0.39 \mathrm{~mm}$ after 60 months of functional loading. Table 3 shows MBL average values, with the corresponding standard deviation, in function of interproximal site (mesial or distal), elapsed time since functional loading (12, 24, 36, 48 and 60 months), type of implant (SH or ST), and type of bone (pristine or grafted). Table 4 displays the data that relate to the association between the independent variables and MBL. Independent samples t-tests were used to examine the effects of gender, history of periodontitis, and smoking. Pearson correlation coefficients were computed for age. Smoking independently influenced bone loss during the observed times at both mesial and distal sites. Likewise, an association between history of periodontitis and increased MBL was observed. Increased MBL was also associated with older age. The two (intergroup, type of bone: pristine vs. grafted) by 2 (intergroup, type implant: SH vs. ST) by 3 (intragroup, times: 12, 24, 36, 48 and 60 months) by 2 (intragroup, sites: mesial vs. distal) repeated-measures ANCOVA, using history of periodontitis, smoking and age as covariates, revealed that peri-implant MBL was similar in grafted and in pristine bone. MBL progression rate was not different between both groups.

Table 3. Mesial and distal MBL (intragroup) around implants placed in posterior maxillary pristine bone (spontaneously healed posterior maxillary extraction sockets) by means of osteotome-mediated sinus floor elevation and in posterior maxillary extraction sockets grafted by 4 to 5 months, (intergroup) in function of elapsed time since functional loading (intragroup)

\begin{tabular}{|c|c|c|c|c|c|c|c|}
\hline \multirow{3}{*}{ Site } & \multirow{3}{*}{ Bone } & \multirow{3}{*}{ Implant } & \multicolumn{5}{|c|}{ MBL (mm) } \\
\hline & & & 1 year & 2 years & 3 years & 4 years & 5 years \\
\hline & & & Mean (SD) & Mean (SD) & Mean (SD) & Mean (SD) & Mean (SD) \\
\hline \multirow{4}{*}{ Mesial } & \multirow{2}{*}{ Pristine } & Short length & $0.07(0.12)$ & $0.11(0.21)$ & $0.18(0.32)$ & $0.21(0.28)$ & $0.33(0.51)$ \\
\hline & & Standard length & $0.06(0.14)$ & $0.12(0.19)$ & $0.16(0.38)$ & $0.23(0.34)$ & $0.30(0.44)$ \\
\hline & \multirow{2}{*}{ Grafted } & Short length & $0.09(0.13)$ & $0.12(0.19)$ & $0.17(0.28)$ & $0.22(0.33)$ & $0.34(0.47)$ \\
\hline & & Standard length & $0.07(0.11)$ & $0.1(0.22)$ & $0.19(0.31)$ & $0.23(0.43)$ & $0.33(0.49)$ \\
\hline \multirow{4}{*}{ Distal } & \multirow{2}{*}{ Pristine } & Short length & $0.08(0.11)$ & $0.13(0.22)$ & $0.17(0.38)$ & $0.24(0.38)$ & $0.37(0.44)$ \\
\hline & & Standard length & $0.07(0.12)$ & $0.11(0.2)$ & $0.19(0.42)$ & $0.22(0.44)$ & $0.35(0.45)$ \\
\hline & \multirow{2}{*}{ Grafted } & Short length & $0.09(0.13)$ & $0.12(0.17)$ & $0.18(0.25)$ & $0.23(0.47)$ & $0.32(0.26)$ \\
\hline & & Standard length & $0.06(0.11)$ & $0.14(0.21)$ & $0.2(0.51)$ & $0.25(0.33)$ & $0.31(0.39)$ \\
\hline
\end{tabular}

$\mathrm{MBL}=$ marginal bone loss; $\mathrm{SD}=$ standard deviation. 
Table 4. Differences between marginal bone loss for gender (females/males), periodontitis (periodontal vs. non-periodontal) and smoking (smokers vs. non-smokers)

\begin{tabular}{|c|c|c|c|c|c|c|c|c|c|}
\hline \multirow[t]{2}{*}{ Year } & \multirow[t]{2}{*}{ Site } & \multicolumn{2}{|c|}{ Gender } & \multicolumn{2}{|c|}{$\begin{array}{c}\text { History of } \\
\text { periodontitis }\end{array}$} & \multicolumn{2}{|c|}{ Smoking } & \multicolumn{2}{|c|}{ Age } \\
\hline & & Mean (SD) & P-value ${ }^{a}$ & Mean (SD) & P-value ${ }^{a}$ & Mean (SD) & P-value ${ }^{a}$ & Mean years & P-value ${ }^{b}$ \\
\hline \multirow{2}{*}{1 year } & Mesial & $0.6(0.13)$ & 0.22 & $0.42(0.19)$ & 0.009 & $0.45(0.38)$ & 0.001 & 0.32 & 0.008 \\
\hline & Distal & $0.07(0.15)$ & 0.28 & $0.38(0.22)$ & 0.022 & $0.51(0.42)$ & 0.004 & 0.28 & 0.009 \\
\hline \multirow{2}{*}{2 years } & Mesial & $0.12(0.15)$ & 0.31 & $0.44(0.23)$ & 0.015 & $0.47(0.48)$ & 0.001 & 0.3 & 0.008 \\
\hline & Distal & $0.14(0.16)$ & 0.37 & $0.41(0.31)$ & 0.014 & $0.52(0.32)$ & 0.007 & 0.32 & 0.009 \\
\hline \multirow{2}{*}{3 years } & Mesial & $0.18(0.25)$ & 0.31 & $0.4(0.33)$ & 0.006 & $0.45(0.33)$ & 0.012 & 0.36 & 0.003 \\
\hline & Distal & $0.19(0.36)$ & 0.38 & $0.38(0.31)$ & 0.015 & $0.55(0.42)$ & 0.013 & 0.38 & 0.006 \\
\hline \multirow{2}{*}{4 years } & Mesial & $0.2(0.25)$ & 0.41 & $0.37(0.35)$ & 0.016 & $0.5(0.29)$ & 0.009 & 0.33 & 0.005 \\
\hline & Distal & $0.19(0.36)$ & 0.35 & $0.39(0.41)$ & 0.008 & $0.51(0.32)$ & 0.013 & 0.31 & 0.002 \\
\hline \multirow{2}{*}{5 years } & Mesial & $0.21(0.22)$ & 0.36 & $0.34(0.45)$ & 0.002 & $0.47(0.39)$ & 0.003 & 0.34 & 0.007 \\
\hline & Distal & $0.22(0.26)$ & 0.48 & $0.33(0.51)$ & 0.003 & $0.49(0.42)$ & 0.008 & 0.35 & 0.009 \\
\hline
\end{tabular}

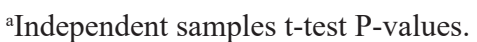

${ }^{b}$ Pearson correlation coefficients for age.

$\mathrm{SD}=$ standard deviation

\section{DISCUSSION}

To our knowledge, this is the first long-term retrospective multicentre cohort study aimed at determining whether implants placed in posterior maxillary pristine bone (spontaneously healed posterior maxillary extraction sockets) using sinus floor elevation with crestal approach, exhibit different success rate, peri-implant soft tissue conditions and radiographic MBL than implants placed according to conventional implant placement protocol in posterior maxillary extraction sockets, grafted by $<6$ months. The influence of other variables such as smoking, history of periodontitis, and type of implant ( $\mathrm{SH}$ and ST) on MBL incidence was also investigated. According to the collected data, no statistically significant differences in success rate and in clinical parameters, such as, the PI, pocket depth, BOP, and gingival recession were observed between two groups and between SH and ST implants. MBL is considered an important prognostic factor in the evaluation of the implant survival [36]. The values accepted as a reasonable guideline for MBL are $1.5 \mathrm{~mm}$ for the first year following loading of the implant and $0.2 \mathrm{~mm}$ of additional loss for each subsequent year [37]. A recent literature review by Ramanauskaite et al. [37], including $7 \mathrm{RCTs}$, reported MBL changes between implants placed into the naturally healed sites or the previously grafted sockets. Two of them revealed no significant difference $[\underline{38}, \underline{39}]$. In contrast, a single study reported higher MBL loss for the implants placed into the naturally healed sites versus grafted sockets [40]. MBL has been associated with multiple factors, such as, surgical trauma [41], prosthetic considerations [42], implant design [43], patient habits [44], implant/abutment connection [45], and bone substratum [46]. However, some key questions on the influence of each specific factor remains unanswered. Since MBL is usually around the coronal end of the implant, differences in biomechanical and biological properties of the tissue that directly interfaces with the implant collar could result in different responses after functional loading. Several studies indicated that porcinederived bone is not completely reabsorbable [20-32]. Non-resorbtion might not only result in shielding of the newly formed bone from physiological stresses necessary for further remodelling, but the presence of residual graft particles could also interfere with the maintenance of marginal bone levels around dental implants [47]. Some authors [47-49], having histologically documented the presence of multinucleated/osteoclastic cells around xenogenic bone residual particles, speculated that these may influence the physiologic bone remodelling process around dental implants. Other authors [29-32], documenting that residual graft particles are completely surrounded by vital bone, suggested that they could provide a biologic support similar to that of the host bone. The effect of biomechanical adaptive responses after functional loading on progressive MBL in grafted site model has been investigated in a finite element analysis study by Inglam et al. [34] using a composite graft (autologous cortical bone and anorganic bovine bone). 
Authors noticed that when the stiffness of the grafted area is less than that of the cancellous bone highlevel strain is primarily distributed at the crestal level, which may promote MBL. Therefore, grafted areas should ideally have certain stiffness (similar or superior to adjacent native bone), so efficient loading forces distribution can be reached due to the exhibited similar values of strain energy density in the crestal cortical, cancellous, and grafted bone [34]. Compared with normal human cancellous bone, anorganic bovine bone has a slightly higher modulus of elasticity and a lower stiffness [50]. Vice versa, the modulus of elasticity and stiffness of porcine xenograft are closer to human trabecular bone than bovine bone [51]. According to outcomes of the present study, it is reasonable to postulate that the porcine derived biomaterial particles might act creating a dense and hard tissue network that provides a biomechanical support to dental implants similar to that of the host bone.

Current knowledge in medicine leads to assume that anything foreign to the body will immediately be signaled by the immune system and a cascade of reactions ensues in parallel to a modulated inflammation, as part of tissue repair (for a detailed description see the reference [52]). The integration of biocompatible materials and titanium dental implants, actually representing a foreign body reaction, is an immune-modulated, multifactorial, and complex healing process where a number of cells and mediators are involved [52,53]. The buildup of osseointegration of biocompatible materials and titanium dental implants seems to be an immunologically and inflammatory-driven process, with the ultimate end to shield off the foreign material placed in the body [53]. The long-term clinical function of this process is dependent on a foreign body equilibrium, that if disturbed may lead to impaired clinical function, through a breakdown process where macrophages are again activated and may further fuse into foreign body giant cells, now seen in much greater numbers, resulting in the start of bone resorption - due to cells such as osteoclasts with different origins and possibly even macrophages degrading more bone than what is formed via osteoblastic activity through complex mechanisms. A series of factors, such as unsuitable biomaterial/ implant designs, suboptimal selection of surgical sites, suboptimal operator skills in tissue manipulation, patients' brittle systemic health, over loading situations and, of course, different degrees of foreign body reaction could to work together to activate the immune system, ultimately shifting the delicate balance between the osteoblast and the osteoclast resulting in implant failures [53]. However, further studies are needed to clarify the precise regulation and the individual input of the inflammatory immune and healing processes in the buildup and breakdown of biomaterials and titanium implant osseointegration.

In contrast to the proposed criterion of implant success, we observed less MBL over an average of 5 years. The implant used in the present study has a $1.8 \mathrm{~mm}$ laser micro-grooved coronal design. Several studies, using implants with these collar features, showed minimal MBL [52]. This has been explained by the capacity of the lasermicrogrooved surface to influence peri-implant soft-tissue response with a perpendicular/functional orientation of connective tissue fibres around the implant collar that protect the peri-implant crestal bone [34].

In the current study, smoking and history of periodontitis negatively influenced MBL with statistical significance regardless of the type of osseous substrate (grafted or pristine) and type of implant (SH or ST). Nonetheless, this is not surprising because both variables have been reported to play an important detrimental role in the maintenance of peri-implant crestal bone. Multiple studies have demonstrated an increased risk of MBL for smokers compared with non-smokers, with odds ratio of peri-implantitis in smokers that range from 3.6 to $4.6[\underline{53}, 54]$. In a recent meta-analysis, MBL in subjects with history of periodontitis was found to be higher than in periodontally healthy subjects (mean difference $=0.61 \mathrm{~mm}$ ) [55] . It has also been shown that the combination of history of periodontitis and smoking increases the risk of peri-implant bone loss [55].

Despite the efforts made by the investigators to comply with high standards of research quality, this study presents some limitations. First, results came from a retrospective study and hence, they require validation by other randomized, controlled, prospective clinical studies. Also, obtaining radiographic MBL measurements from CBCT scans would have provided more accuracy and the possibility of performing a three-dimensional analysis.

\section{CONCLUSIONS}

The data from this study indicate that the conditions of the soft tissues and the marginal bone level at implants with a laser-microgrooved collar placed in posterior maxillary extraction sockets grafted 
by 4 to 5 months, and in posterior maxillary pristine bone (spontaneously healed posterior maxillary extraction sockets) using osteotome-mediated sinus floor elevation, were similar after an observation period of 5 years in this patient population. Hence, the implant coronal anchorage provided by nonaugmented or partially augmented bone was capable of withstanding prosthetic loading.

\section{ACKNOWLEDGMENTS AND DISCLOSURE STATEMENTS}

Funding: the study was performed with a grant of BioHorizons Inc. (Birmingham, Alabama, USA) that provided materials.

The Authors report no conflict of interest.

\section{REFERENCES}

1. Van der Weijden F, Dell'Acqua F, Slot DE. Alveolar bone dimensional changes of post-extraction sockets in humans: a systematic review. J Clin Periodontol. 2009 Dec;36(12):1048-58. [Medline: 19929956] [doi: 10.1111/j.1600-051X.2009.01482.x]

2. Amler MH, Johnson PL, Salman I. Histological and histochemical investigation of human alveolar socket healing in undisturbed extraction wounds. J Am Dent Assoc. 1960 Jul;61:32-44. [Medline: 13793201] [doi: 10.14219/jada.archive.1960.0152]

3. Schropp L, Wenzel A, Kostopoulos L, Karring T. Bone healing and soft tissue contour changes following singletooth extraction: a clinical and radiographic 12-month prospective study. Int J Periodontics Restorative Dent. 2003 Aug;23(4):313-23. [Medline: 12956475]

4. Araújo MG, Lindhe J. Ridge alterations following tooth extraction with and without flap elevation: an experimental study in the dog. Clin Oral Implants Res. 2009 Jun;20(6):545-9. [Medline: 19515033] [doi: 10.1111/j.1600-0501.2008.01703.x]

5. Trombelli L, Farina R, Marzola A, Bozzi L, Liljenberg B, Lindhe J. Modeling and remodeling of human extraction sockets. J Clin Periodontol. 2008 Jul;35(7):630-9. [Medline: 18498382] [doi: 10.1111/j.1600-051X.2008.01246.x]

6. Pietrokovski J, Massler M. Alveolar ridge resorption following tooth extraction. J Prosthet Dent. 1967 Jan;17(1):21-7. [Medline: 5224784] [doi: 10.1016/0022-3913(67)90046-7]

7. Araújo MG, Sukekava F, Wennström JL, Lindhe J. Tissue modeling following implant placement in fresh extraction sockets. Clin Oral Implants Res. 2006 Dec;17(6):615-24. [Medline: 17092218] [doi: 10.1111/j.1600-0501.2006.01317.x]

8. Esposito M, Felice P, Worthington HV. Interventions for replacing missing teeth: augmentation procedures of the maxillary sinus. Cochrane Database Syst Rev. 2014 May 13;(5):CD008397. [Medline: 24825543] [doi: 10.1002/14651858.CD008397.pub2]

9. Raghoebar GM, Onclin P, Boven GC, Vissink A, Meijer HJA. Long-term effectiveness of maxillary sinus floor augmentation: A systematic review and meta-analysis. J Clin Periodontol. 2019 Jun;46 Suppl 21:307-318. [Medline: 30624789] [doi: 10.1111/jcpe.13055]

10. Stacchi C, Andolsek F, Berton F, Perinetti G, Navarra CO, Di Lenarda R. Intraoperative Complications During Sinus Floor Elevation with Lateral Approach: A Systematic Review. Int J Oral Maxillofac Implants. 2017 May/Jun;32(3):e107-e118. [Medline: 28494033] [doi: 10.11607/jomi.4884]

11. Summers RB. A new concept in maxillary implant surgery: the osteotome technique. Compendium. 1994 Feb;15(2):152, 154-6, 158 passim; quiz 162. [Medline: $\underline{\text { 8055503] }}$

12. Stelzle F, Benner KU. Evaluation of different methods of indirect sinus floor elevation for elevation heights of 10mm: an experimental ex vivo study. Clin Implant Dent Relat Res. 2011 Jun;13(2):124-33. [Medline: 19681924] [doi: $10.1111 / \mathrm{j} .1708-8208.2009 .00190 . \mathrm{x}]$

13. Rosen PS, Summers R, Mellado JR, Salkin LM, Shanaman RH, Marks MH, Fugazzotto PA. The bone-added osteotome sinus floor elevation technique: multicenter retrospective report of consecutively treated patients. Int J Oral Maxillofac Implants. 1999 Nov-Dec;14(6):853-8. [Medline: 10612923]

14. Mardas N, Trullenque-Eriksson A, MacBeth N, Petrie A, Donos N. Does ridge preservation following tooth extraction improve implant treatment outcomes: a systematic review: Group 4: Therapeutic concepts \& methods. Clin Oral Implants Res. 2015 Sep;26 Suppl 11:180-201. [Medline: 26078004] [doi: 10.1111/clr.12639]

15. Hämmerle $\mathrm{CH}$, Araújo MG, Simion M; Osteology Consensus Group 2011. Evidence-based knowledge on the biology and treatment of extraction sockets. Clin Oral Implants Res. 2012 Feb;23 Suppl 5:80-2. [Medline: 22211307] [doi: $10.1111 / \mathrm{j} .1600-0501.2011 .02370 . \mathrm{x}]$

16. Iocca O, Farcomeni A, Pardiñas Lopez S, Talib HS. Alveolar ridge preservation after tooth extraction: a Bayesian Network meta-analysis of grafting materials efficacy on prevention of bone height and width reduction. J Clin Periodontol. 2017 Jan;44(1):104-114. [Medline: 27712001] [doi: 10.1111/jcpe.12633]

17. Vignoletti F, Matesanz P, Rodrigo D, Figuero E, Martin C, Sanz M. Surgical protocols for ridge preservation after tooth extraction. A systematic review. Clin Oral Implants Res. 2012 Feb;23 Suppl 5:22-38. [Medline: 22211304] [doi: $10.1111 / \mathrm{j} .1600-0501.2011 .02331 . \mathrm{x}]$ 
18. Vittorini Orgeas G, Clementini M, De Risi V, de Sanctis M. Surgical techniques for alveolar socket preservation: a systematic review. Int J Oral Maxillofac Implants. 2013 Jul-Aug;28(4):1049-61. [Medline: 23869363] [doi: $10.11607 /$ jomi.2670]

19. de Misquita MR, Bentini R, Goncalves F. The performance of bone tissue engineering scaffolds in in vivo animal models: A systematic review. J Biomater Appl. 2016 Nov;31(5):625-636. [Medline: 27334129] [doi: 10.1177/0885328216656476]

20. Chan HL, Lin GH, Fu JH, Wang HL. Alterations in bone quality after socket preservation with grafting materials: a systematic review. Int J Oral Maxillofac Implants. 2013 May-Jun;28(3):710-20. [Medline: 23748301] [doi: $10.11607 /$ jomi.2913]

21. Barallat L, Ruíz-Magaz V, Levi PA Jr, Mareque-Bueno S, Galindo-Moreno P, Nart J. Histomorphometric results in ridge preservation procedures comparing various graft materials in extraction sockets with nongrafted sockets in humans: a systematic review. Implant Dent. 2014 Oct;23(5):539-54. [Medline: 25192153] [doi: 10.1097/ID.0000000000000124]

22. Atieh MA, Payne AG, Duncan WJ, de Silva RK, Cullinan MP. Immediate placement or immediate restoration/loading of single implants for molar tooth replacement: a systematic review and meta-analysis. Int J Oral Maxillofac Implants. 2010 Mar-Apr;25(2):401-15. [Medline: 20369102]

23. Clementini M, Tiravia L, De Risi V, Vittorini Orgeas G, Mannocci A, de Sanctis M. Dimensional changes after immediate implant placement with or without simultaneous regenerative procedures: a systematic review and meta-analysis. J Clin Periodontol. 2015 Jul;42(7):666-77. [Medline: 26073267] [doi: 10.1111/jepe.12423]

24. Cardaropoli D, Tamagnone L, Roffredo A, Gaveglio L, Cardaropoli G. Socket preservation using bovine bone mineral and collagen membrane: a randomized controlled clinical trial with histologic analysis. Int J Periodontics Restorative Dent. 2012 Aug;32(4):421-30. [Medline: 22577648]

25. Barone A, Ricci M, Tonelli P, Santini S, Covani U. Tissue changes of extraction sockets in humans: a comparison of spontaneous healing vs. ridge preservation with secondary soft tissue healing. Clin Oral Implants Res. 2013 Nov;24(11):1231-7. [Medline: 22784417] [doi: 10.1111/j.1600-0501.2012.02535.x]

26. Levi I, Halperin-Sternfeld M, Horwitz J, Zigdon-Giladi H, Machtei EE. Dimensional changes of the maxillary sinus following tooth extraction in the posterior maxilla with and without socket preservation. Clin Implant Dent Relat Res. 2017 Oct;19(5):952-958. [Medline: 28745002] [doi: 10.1111/cid.12521]

27. Nannmark U, Sennerby L. The bone tissue responses to prehydrated and collagenated cortico-cancellous porcine bone grafts: a study in rabbit maxillary defects. Clin Implant Dent Relat Res. 2008 Dec;10(4):264-70. [Medline: 18241216] [doi: $10.1111 /$ j.1708-8208.2007.00080.x]

28. Giuliani A, Iezzi G, Mazzoni S, Piattelli A, Perrotti V, Barone A. Regenerative properties of collagenated porcine bone grafts in human maxilla: demonstrative study of the kinetics by synchrotron radiation microtomography and light microscopy. Clin Oral Investig. 2018 Jan;22(1):505-513. [Medline: 28577053] [doi: 10.1007/s00784-017-2139-6]

29. Guarnieri R, Testarelli L, Stefanelli L, De Angelis F, Mencio F, Pompa G, Di Carlo S. Bone Healing in Extraction Sockets Covered With Collagen Membrane Alone or Associated With Porcine-Derived Bone Graft: a Comparative Histological and Histomorphometric Analysis. J Oral Maxillofac Res. 2017 Dec 31;8(4):e4. [Medline: 29435206] [PMC free article: 5806041] [doi: 10.5037/jomr.2017.8404]

30. Calvo-Guirado JL, Gómez-Moreno G, Guardia J, Ortiz-Ruiz A, Piatelli A, Barone A, Martínez-González JM, MeseguerOlmo L, López-Marí L, Dorado CB. Biological response to porcine xenograft implants: an experimental study in rabbits. Implant Dent. 2012 Apr;21(2):112-7. [Medline: 22440978] [doi: 10.1097/ID.0b013e3182425991]

31. Barone A, Aldini NN, Fini M, Giardino R, Calvo Guirado JL, Covani U. Xenograft versus extraction alone for ridge preservation after tooth removal: a clinical and histomorphometric study. J Periodontol. 2008 Aug;79(8):1370-7. [Medline: 18672985] [doi: 10.1902/jop.2008.070628]

32. Barone A, Toti P, Quaranta A, Alfonsi F, Cucchi A, Negri B, Di Felice R, Marchionni S, Calvo-Guirado JL, Covani U, Nannmark U. Clinical and Histological changes after ridge preservation with two xenografts: preliminary results from a multicentre randomized controlled clinical trial. J Clin Periodontol. 2017 Feb;44(2):204-214. [Medline: 27883211] [doi: $10.1111 /$ jepe.12655]

33. Fanuscu MI, Vu HV, Poncelet B. Implant biomechanics in grafted sinus: a finite element analysis. J Oral Implantol. 2004;30(2):59-68. [Medline: 15119454] [doi: 10.1563/0.674.1]

34. Inglam S, Suebnukarn S, Tharanon W, Apatananon T, Sitthiseripratip K. Influence of graft quality and marginal bone loss on implants placed in maxillary grafted sinus: a finite element study. Med Biol Eng Comput. 2010 Jul;48(7):681-9. [Medline: 20429039] [doi: 10.1007/s11517-010-0584-3]

35. Huang HL, Fuh LJ, Ko CC, Hsu JT, Chen CC. Biomechanical effects of a maxillary implant in the augmented sinus: a three-dimensional finite element analysis. Int J Oral Maxillofac Implants. 2009 May-Jun;24(3):455-62. [Medline: 19587867$]$

36. Albrektsson T, Donos N; Working Group 1. Implant survival and complications. The Third EAO consensus conference 2012. Clin Oral Implants Res. 2012 Oct;23 Suppl 6:63-5. [Medline: 23062128] [doi: 10.1111/j.1600-0501.2012.02557.x]

37. Ramanauskaite A, Borges T, Almeida BL, Correia A. Dental Implant Outcomes in Grafted Sockets: a Systematic Review and Meta-Analysis. J Oral Maxillofac Res. 2019 Sep 5;10(3):e8. [Medline: 31620270] [PMC free article: 6788428] [doi: 10.5037/jomr.2019.10308] 
38. Cardaropoli D, Tamagnone L, Roffredo A, Gaveglio L. Evaluation of Dental Implants Placed in Preserved and Nonpreserved Postextraction Ridges: A 12-Month Postloading Study. Int J Periodontics Restorative Dent. 2015 Sep-Oct;35(5):677-85. [Medline: 26357697] [doi: 10.11607/prd.2309]

39. Barone A, Orlando B, Cingano L, Marconcini S, Derchi G, Covani U. A randomized clinical trial to evaluate and compare implants placed in augmented versus non-augmented extraction sockets: 3-year results. J Periodontol. 2012 Jul;83(7): 836-46. [Medline: 22141358] [doi: 10.1902/jop.2011.110205]

40. Marconcini S, Giammarinaro E, Derchi G, Alfonsi F, Covani U, Barone A. Clinical outcomes of implants placed in ridgepreserved versus nonpreserved sites: A 4-year randomized clinical trial. Clin Implant Dent Relat Res. 2018 Dec;20(6): 906-914. [Medline: 30307130] [doi: 10.1111/cid.12682]

41. Qian J, Wennerberg A, Albrektsson T. Reasons for marginal bone loss around oral implants. Clin Implant Dent Relat Res. 2012 Dec;14(6):792-807. [Medline: 23198697] [doi: 10.1111/cid.12014]

42. Cardaropoli G, Lekholm U, Wennström JL. Tissue alterations at implant-supported single-tooth replacements: a 1-year prospective clinical study. Clin Oral Implants Res. 2006 Apr;17(2):165-71. [Medline: 16584412] [doi: $10.1111 / \mathrm{j} .1600-0501.2005 .01210 . \mathrm{x}]$

43. Canullo L, Fedele GR, Iannello G, Jepsen S. Platform switching and marginal bone-level alterations: the results of a randomized-controlled trial. Clin Oral Implants Res. 2010 Jan;21(1):115-21. [Medline: 20070752] [doi: 10.1111/j.1600-0501.2009.01867.x]

44. Galindo-Moreno P, Fauri M, Avila-Ortiz G, Fernández-Barbero JE, Cabrera-León A, Sánchez-Fernández E. Influence of alcohol and tobacco habits on peri-implant marginal bone loss: a prospective study. Clin Oral Implants Res. 2005 Oct;16(5):579-86. [Medline: 16164465] [doi: 10.1111/j.1600-0501.2005.01148.x]

45. Suarez F, Chan HL, Monje A, Galindo-Moreno P, Wang HL. Effect of the timing of restoration on implant marginal bone loss: a systematic review. J Periodontol. 2013 Feb;84(2):159-69. [Medline: 22509755] [doi: 10.1902/jop.2012.120099]

46. Galindo-Moreno P, Fernández-Jiménez A, Avila-Ortiz G, Silvestre FJ, Hernández-Cortés P, Wang HL. Marginal bone loss around implants placed in maxillary native bone or grafted sinuses: a retrospective cohort study. Clin Oral Implants Res. 2014 Mar;25(3):378-384. [Medline: 23421476] [doi: 10.1111/clr.12122]

47. Araújo M, Linder E, Wennström J, Lindhe J. The influence of Bio-Oss Collagen on healing of an extraction socket: an experimental study in the dog. Int J Periodontics Restorative Dent. 2008 Apr;28(2):123-35. [Medline: 18546808]

48. Araújo M, Linder E, Lindhe J. Effect of a xenograft on early bone formation in extraction sockets: an experimental study in dog. Clin Oral Implants Res. 2009 Jan;20(1):1-6. [Medline: 19126101] [doi: 10.1111/j.1600-0501.2008.01606.x]

49. Piattelli M, Favero GA, Scarano A, Orsini G, Piattelli A. Bone reactions to anorganic bovine bone (Bio-Oss) used in sinus augmentation procedures: a histologic long-term report of 20 cases in humans. Int J Oral Maxillofac Implants. 1999 Nov-Dec;14(6):835-40. [Medline: 10612920]

50. Yildirim M, Spiekermann H, Biesterfeld S, Edelhoff D. Maxillary sinus augmentation using xenogenic bone substitute material Bio-Oss in combination with venous blood. A histologic and histomorphometric study in humans. Clin Oral Implants Res. 2000 Jun;11(3):217-29. [Medline: 11168213] [doi: 10.1034/j.1600-0501.2000.011003217.x]

51. Park SA, Shin JW, Yang YI, Kim YK, Park KD, Lee JW, Jo IH, Kim YJ. In vitro study of osteogenic differentiation of bone marrow stromal cells on heat-treated porcine trabecular bone blocks. Biomaterials. 2004 Feb;25(3):527-35. [Medline: 14585702] [doi: 10.1016/S0142-9612(03)00553-2]

52. Trindade R, Albrektsson T, Tengvall P, Wennerberg A. Foreign Body Reaction to Biomaterials: On Mechanisms for Buildup and Breakdown of Osseointegration. Clin Implant Dent Relat Res. 2016 Feb;18(1):192-203. [Medline: 25257971] [doi: $10.1111 / \mathrm{cid} .12274]$

53. Albrektsson T, Chrcanovic B, Jacobsson M, Wennerberg A. Osseointegration of Implants - A Biological and Clinical Overview. JSM Dent Surg. 20172(3): 1022. [URL: https://www.jscimedcentral.com/DentalSurgery/dentalsurgery-2-1022. pdf]

54. Ketabi M, Deporter D. The effects of laser microgrooves on hard and soft tissue attachment to implant collar surfaces: a literature review and interpretation. Int J Periodontics Restorative Dent. 2013 Nov-Dec;33(6):e145-52. [Medline: 24116369] [doi: 10.11607/prd.1629]

55. Nitzan D, Mamlider A, Levin L, Schwartz-Arad D. Impact of smoking on marginal bone loss. Int J Oral Maxillofac Implants. 2005 Jul-Aug;20(4):605-9. [Medline: 16161745]

56. Heitz-Mayfield LJ, Huynh-Ba G. History of treated periodontitis and smoking as risks for implant therapy. Int J Oral Maxillofac Implants. 2009;24 Suppl:39-68. [Medline: 19885434]

57. Safii SH, Palmer RM, Wilson RF. Risk of implant failure and marginal bone loss in subjects with a history of periodontitis: a systematic review and meta-analysis. Clin Implant Dent Relat Res. 2010 Sep;12(3):165-74. [Medline: 19438942] [doi: 10.1111/j.1708-8208.2009.00162.x] 


\section{To cite this article:}

Guarnieri R, Savio L, Bermonds A, Testarelli L.

Implants with a Laser-microgrooved Collar Placed in Grafted Posterior Maxillary Extraction Sockets and in Crestally Grafted Sinuses: a 5-Year Multicentre Retrospective Study

J Oral Maxillofac Res 2020;11(4):e2

URL: http://www.ejomr.org/JOMR/archives/2020/4/e2/v11n4e2.pdf

doi: $\underline{10.5037 / j o m r .2020 .11402}$

Copyright (C) Guarnieri R, Savio L, Bermonds A, Testarelli L. Published in the JOURNAL OF ORAL \& MAXILLOFACIAL RESEARCH (http://www.ejomr.org), 31 Dcember 2020.

This is an open-access article, first published in the JOURNAL OF ORAL \& MAXILLOFACIAL RESEARCH, distributed under the terms of the Creative Commons Attribution-Noncommercial-No Derivative Works 3.0 Unported License, which permits unrestricted non-commercial use, distribution, and reproduction in any medium, provided the original work and is properly cited. The copyright, license information and link to the original publication on (http://www.ejomr.org) must be included. 